\title{
Enraizamento in vitro de pereira (Pyrus communis L.) cv. Carrick
}

\author{
In vitro rooting of pear tree (Pyrus communis L.) cv. Carrick
}

Alan Cristiano Erig ${ }^{1}$ Márcia Wulff Schuch ${ }^{2}$ Eugênia Jacira Bolacel Braga ${ }^{3}$ \begin{abstract}
O objetivo do presente trabalho foi avaliar o efeito
do ácido naftalenoacético (ANA) e do carvão ativado no
enraizamento in vitro de pereira (Pyrus communis L.) cv.
Carrick. Para tanto, microestacas de pereira com
aproximadamente 0,8 a 1cm de comprimento foram utilizadas
como explantes. Os tratamentos constituíram-se de três
concentração de ANA no meio de cultura $(0 ; 3,2$ e $6,4 \mu M)$ e
de duas concentração de carvão ativado $(0$ e $1 \%)$. A partir
dos resultados obtidos no experimento, conclui-se que o ANA
nas concentrações de 3,2 e $6,4 \mu M$ e na ausência de carvão
ativado no meio de cultura, possibilitou um melhor
enraizamento de pereira cv. Carrick. RESUMO
\end{abstract} Palavras-chave: microestacas; cultura de tecidos; ANA; carvão ativado.

\section{ABSTRACT}

The aim of the present work was to evaluate the effects of naphthaleneacetic acid (NAA) and activated charcoal on the in vitro rooting of the pear tree (Pyrus communis L.) cv. Carrick. Therefore pear tree microshoots with approximately 0.8 to $1 \mathrm{~cm}$ of length were used as explant. The treatments were constituted of three concentration of NAA in the culture medium $(0 ; 3.2$ and $6.4 \mu \mathrm{M})$ and two concentration of activated charcoal ( 0 and 1\%). NAA in the concentration of 3.2 and $6.4 \mu \mathrm{M}$ and in the absence of activated charcoal in the culture medium, showed better rooting rate to pear tree cv. Carrick.

Key words: microcuttings; tissue culture; NAA; activated charcoal.
O cultivo da pereira dá-se em todo o mundo, sendo a Europa e a Ásia, as regiões de maior produção. No Brasil, seu cultivo ainda é reduzido, apesar de alguns estados, principalmente Rio Grande do Sul e Santa Catarina, possuírem algumas regiões climáticas favoráveis à sua produção. Um dos obstáculos para o desenvolvimento da cultura da pereira no Brasil está na falta de mudas para atender os fruticultores. As pereiras não podem ser propagadas a partir de sementes, devido ao seu elevado nível de heterozigosidade.

A técnica de micropropagação tem sido desenvolvida para inúmeras espécies de árvores frutíferas, como um método alternativo e rápido de propagação vegetativa. De acordo com FACHINELLO et al. (1995), a propagação in vitro de porta-enxerto de pereira é viável. Entretanto, segundo PASQUAL et al. (1990) o enraizamento in vitro de cultivares-copa não é tão fácil como nas cultivares porta-enxerto.

O objetivo do presente trabalho foi o de avaliar a influência do ANA e do carvão ativado no enraizamento in vitro de pereira (Pyrus communis L.) cultivar Carrick.

O experimento foi realizado no Laboratório de Cultura de Células e Tecidos de Plantas, Departamento de Botânica do Instituto de Biologia, da UFPel, RS. Microestacas de pereira cv. Carrick, com

${ }^{1}$ Engenheiro Agrônomo, M.Sc., Aluno do Programa de Pós-graduação em Agronomia, área de concentração em Fruticultura de Clima Temperado. Faculdade de Agronomia Eliseu Maciel, Universidade Federal de Pelotas (UFPel), CP 354, 96.010-900, Pelotas, RS. E-mail: acerig@ufpel.tche.br Autor para correspondência.

${ }^{2}$ Engenheiro Agrônomo, Doutor, Professora, Departamento de Fitotecnia, Faculdade de Agronomia Eliseu Maciel/UFPel, Pelotas, RS. E-mail: marciaws@ufpel.tche.br

${ }^{3}$ Biólogo, MSc., Aluno do Programa de Pós-graduação em Biotecnologia, Centro de Biotecnologia, Instituto de Biologia/UFPel. Pelotas, RS. 
aproximadamente 0,8 a $1 \mathrm{~cm}$ de comprimento foram utilizadas como explantes. Os tratamentos constituíram-se de três concentração de $\operatorname{ANA}(0 ; 3,2$ e $6,4 \mu \mathrm{M}$ ) e de duas concentrações de carvão ativado no meio de cultura (0 e 1\%), totalizando 6 tratamentos.

$\mathrm{O}$ meio de cultura constituiu-se dos sais e vitaminas de MS (MURASHIGE \& SKOOG, 1962) sendo os sais reduzidos a $3 / 4$ da concentração original, com exceção do ferro, que permaneceu na concentração normal, adicionado de $100 \mathrm{mg} . \mathrm{L}^{-1}$ de mioinositol, 30g. $\mathrm{L}^{-1}$ de sacarose e 6g. $\mathrm{L}^{-1}$ de ágar. $\mathrm{O}$ pH do meio de cultura foi ajustado para 5,8 antes da inclusão do carvão ativado e do ágar e, posteriormente, autoclavado a $121^{\circ} \mathrm{C}$ e 1,5 atm por 15 minutos. Foram utilizados frascos de $200 \mathrm{~mL}$ com $30 \mathrm{~mL}$ de meio de cultura. Após a inoculação, os frascos com os explantes foram transferidos para sala de crescimento com 16 horas de fotoperíodo, temperatura de $25 \pm 2^{\circ} \mathrm{C}$ e densidade de fluxo de fótons do período de luz de $42 \mu \mathrm{mol} \cdot \mathrm{m}^{-2} \cdot \mathrm{s}^{-1}$.

Utilizou-se o delineamento experimental inteiramente casualizado em esquema fatorial ( $3 \times 2)$, com seis repetições por tratamento. Cada repetição constituiu-se de um frasco com cinco explantes. Aos 30 dias de cultivo, avaliou-se a percentagem de enraizamento, o número médio de raízes por explante e o comprimento da raiz mais desenvolvida. Os dados foram submetidos à análise de variância e as médias dos tratamentos comparadas estatisticamente pelo teste de Duncan em nível de 5\% de probabilidade de erro, através do uso do "software" estatístico SANEST (ZONTA\& MACHADO, 1987).

Houve efeito significativo da interação entre concentrações de ANA e carvão ativado no meio de cultura, para as três variáveis avaliadas. Quando o carvão ativado não foi adicionado ao meio de cultura, a percentagem de enraizamento foi de 25,6 e 32,91\%, respectivamente, com 3,2 e 6,4 $\mu \mathrm{M}$ de ANA (Tabela 1). FARIAS et al. (1995) trabalhando com Pyrus calleryana D-6, obtiveram até $50 \%$ de enraizamento utilizando $6,4 \mu \mathrm{M}$ de ANA. Quando não se utilizou ANA no meio de cultura, a percentagem de enraizamento foi nula, o que mostra a importância deste regulador de crescimento para o enraizamento da pereira cv. Carrick. Já CENTELLAS et al. (1999) observaram que houve cerca de $5 \%$ de formação de raízes na macieira cv. Fred Hough, na ausência de ANA no meio de cultivo. Deve-se considerar que as espécies e gêneros utilizadas nos experimentos são diferentes, justificando os distintos resultados.

Com a utilização de $1 \%$ de carvão ativado no meio de cultura, não houve enraizamento das microestacas de pereira, independentemente da concentração de ANA utilizada (Tabela 1). Pelos resultados obtidos, verifica-se que, para o enraizamento in vitro de pereira cv. Carrick, a utilização de carvão ativado no meio de cultura não favorece o enraizamento, provavelmente, devido à retenção de auxinas diminuindo assim o seu efeito. De acordo com GRATTAPAGLIA \& MACHADO (1998), o carvão ativado em concentrações de 0,1 a $2 \%$ pode ser benéfico em alguns casos. Fisicamente, ele simula a condição de escuro, no qual as raízes normalmente se desenvolvem melhor. Quimicamente, o carvão ativado tem efeito adsorvente, retendo parte de todos os elementos que compõem o meio. Entretanto, a adição de carvão ao meio de cultivo nem sempre tem se mostrado vantajoso. NICOLOSO et al. (2001) verificaram que a percentagem de enraizamento em Pfaffia glomerata não foi influenciada pela presença de carvão ativado no meio de cultura.

Pode-se observar na tabela 1 , que de forma semelhante ao enraizamento, o número médio de raízes por explante e o comprimento da raiz mais

Tabela 1 - Percentagem de enraizamento, número médio de raízes por explante e comprimento da raiz mais desenvolvida em microestacas de pereira cv. Carrick, em função da concentração de ANA e de carvão ativado no meio de cultura. UFPel, RS. 2002.

\begin{tabular}{|c|c|c|c|c|c|c|}
\hline \multirow[t]{3}{*}{ ANA $(\mu \mathbf{M})$} & \multicolumn{2}{|c|}{ Enraizamento (\%) } & \multicolumn{2}{|c|}{$\begin{array}{l}\text { Número médio de raízes por } \\
\text { explante }\end{array}$} & \multicolumn{2}{|c|}{ Comprimento da raiz mais desenvolvida $(\mathrm{cm})$} \\
\hline & \multicolumn{2}{|c|}{ carvão (\%) } & \multicolumn{2}{|c|}{ carvão (\%) } & \multicolumn{2}{|c|}{ carvão (\%) } \\
\hline & 0 & 1 & 0 & 1 & 0 & 1 \\
\hline 0 & $0,00 \mathrm{bA} *$ & $0,00 \mathrm{aA}$ & $0,00 \mathrm{cA}$ & $0,00 \mathrm{aA}$ & $0,00 \mathrm{cA}$ & $0,00 \mathrm{aA}$ \\
\hline 3,2 & $25,60 \mathrm{aA}$ & $0,00 \mathrm{aB}$ & $0,97 \mathrm{bA}$ & $0,00 \mathrm{aB}$ & $0,92 \mathrm{bA}$ & $0,00 \mathrm{aB}$ \\
\hline 6,4 & $32,91 \mathrm{aA}$ & $0,00 \mathrm{aB}$ & $1,67 \mathrm{aA}$ & $0,00 \mathrm{aB}$ & $1,78 \mathrm{aA}$ & $0,00 \mathrm{aB}$ \\
\hline Média geral & \multicolumn{2}{|c|}{10,98} & \multicolumn{2}{|c|}{0,92} & \multicolumn{2}{|c|}{0,45} \\
\hline CV $(\%)$ & \multicolumn{2}{|c|}{69,30} & \multicolumn{2}{|c|}{19,40} & \multicolumn{2}{|c|}{89,63} \\
\hline
\end{tabular}

* Médias não seguidas de letras iguais, minúscula na vertical e maiúscula na horizontal, diferem pelo teste de Duncan em nível de $5 \%$ de probabilidade de erro. 
desenvolvida aumentaram com a concentração de ANA e ausência de carvão ativado no meio de cultura. Como não houve enraizamento, quando se utilizou $1 \%$ de carvão ativado no meio de cultura, independentemente da concentração de ANA, o número médio de raízes e o comprimento da raiz mais desenvolvida também foram nulos.

Conclui-se que o ácido naftalenoacético nas concentrações de 3,2 e 6,4 $\mu \mathrm{M}$ e na ausência de carvão ativado no meio de cultura, possibilitou um melhor enraizamento de pereira cv. Carrick.

\section{REFERÊNCIASBIBLIOGRÁFICAS}

CENTELLAS, A.Q. et al. Efeito de auxinas sintéticas no enraizamento in vitro da macieira. Pesquisa Agropecuária Brasileira, Brasília, v.34, n.2, p.181-186, 1999.

FACHINELLO, J.C. et al. Propagação de plantas frutíferas de clima temperado. Pelotas : UFPel, 1995. 179p.
FARIAS, P.C.M.; PETERS, J.A.; NAKASU, B.H. Micropropagação de porta-enxerto de pereira Pyrus calleryana D-6. Revista Brasileira de Fruticultura, Cruz das Almas, v.17, n.1, p.109-120, 1995.

GRATTAPAGLIA, D.; MACHADO, M.A. Micropropagação. In: TORRES, A.C.; CALDAS, L.S.; BUSO, J.A. Cultura de tecidos e transformação genética de plantas. Brasília : SPI/Embrapa - CNPH, 1998. V.1, p.183-260.

MURASHIGE, T.; SKOOG, F. A revised medium for rapid growth and biossay with tobacco tissue cultures. Physiologia Plantarum, Copenhagen, v.15, p.473-497, 1962.

NICOLOSO, F.T. et al. Micropropagação do Ginseng Brasileiro [Pfaffia glomerata (Spreng.) Pedersen]. Revista Brasileira de Plantas Medicinais, Botucatu, v.3, n.2, p.11-18, 2001.

PASQUAL, M. et al. Influência de diversos fatores sobre a multiplicação do porta-enxerto de pereira Pyrus calleryana Dec. in vitro. Ciência e Prática, Lavras, v.14, n.1, p.2834, 1990.

ZONTA, E.P.; MACHADO, A.A. SANEST - Sistema de análise estatística para microcomputadores. Pelotas: DMEC/IFM/UFPel, 1987. 138p. 